논 문22-10-13

폴리머 절연암을 이용한 송전선로 전압 승압에 관한 연구

\title{
A Study on the Voltage Upgrading of Transmission Lines using Polymer Insulation Arm
}

\author{
이원 교 ${ }^{1, a}$, 이정원 ${ }^{1}$, 강연욱 ${ }^{1}$, 이동일 ${ }^{1}$ \\ (Won-Kyo Lee ${ }^{1, a}$, Jung-Won Lee', Yeon-Woog Kang', and Dong-il Lee')
}

\begin{abstract}
The large increase in the use of electricity has resulted in an ever-growing electric power demand. It has created the need for the construction of power transmission facility located close to the load centers and it also has to require wide right-of-way and large lots, that are not always available, for especially the installation of the towers. The difficulties in acquiring right-of-way have put pressure on energy companies to either upgrade a line on an existing right-of-way to higher voltage or build a new line on a narrow right-of-way. This paper presents the design of a compact tower with polymer Insulation arm, in order to reduce the separation between phases. the compact tower can be built on a narrow right-of-way. the compact tower can be designed based on $345 \mathrm{kV}$ Tower regarding electrical clearances and right of way, therefore the conventional $154 \mathrm{kV}$ Tower can be upgrading transmission line voltages have moved to $345 \mathrm{kV}$ levels.
\end{abstract}

Key Words : Compact tower, Polymer arm, Tower design, Right-of-way

\section{1. 서 론}

전력수요의 지속적인 증가와 수요의 지역적 불 균형으로 송전선로 건설은 불가피한 반면 송전선 로 건설에 따른 지역발전 저해, 지가하락, 조망권 저해 등을 사유로 송전선로 경과지 확보가 전력산 업의 최대 현안으로 부각되고 있는 실정이며, 향후 송전설비 건설에 따른 보상비와 건설비가 크게 증 가될 것으로 예상되고 있다. 또한 송전선로 건설에 따른 민원발생 강도가 해마다 증가하고 있으며, 이 에 따라 사업기간이 장기화에 따른 원활한 전력공 급 지장 및 투자비 증가 로 국가경제에 막대한 지 장을 초래하고 있다. 따라서 송전선로 건설시 필요 한 경과지의 점유를 최소화하고 친환경적이며 대

1. 한국전력공사 전력연구원 송배전연구소

(대전시 유성구 문지동 103-16)

a. Corresponding Author : leewonkyo@kepco.co.kr

접수일자 : 2009. 8. 12

1차 심사 : 2009. 8. 31

심사완료 : 2009. 9. 7
용량 송전이 가능한 새로운 기술의 도입이 절실히 요구되고 있다.

그러나 지금까지 건설되어온 철탑은 첱탑 주주 재 및 암이 앵글 혹은 파이프 형태로 제작된 도전 체이기 때문에 철탑과 전선 사이에 자기 애자를 사용한 절연이격거리 확보가 필요하고 이러한 점 때문에 철탑높이 및 폭을 축소하는데 한계가 있다. 이러한 문제를 해결하기 위한 방안으로 비도전체 인 폴리머 등을 으로 구성된 절연 암을 이용한 컴 팩트 타워 설계 및 시공기술이 연구 개발 및 적용 되고 있으며 국내 역시 이러한 기술의 확보가 필 요하다[1]. 절연물을 활용한 컴팩트 타워기술은 절 연물의 구조적 형태의 변화를 통한 송전시스템의 소형화 기술로서 환경친화적이고 효율성과 경제성 을 동시에 만족하는 특징을 가지고 있다[2,3].

절연물로 채택되어 사용되는 폴리머 절연물은 국내의 배전급 절연물뿐만 아니라 전철용 절연물 과 초고압의 대형 절연물에도 확대 적용중이다.

본 논문에서는 $345 \mathrm{kV}$ 용 철탑 설계시 필요한 과전압 해석, 절연협조거리, 뇌사고율을 검토하여, 
기존 $154 \mathrm{kV}$ 송전철탑 크기를 기준으로 폴리머 절 연암을 이용한 철탑의 컴팩트화 기법을 적용한 절 연협조 설계 기법을 제시하고자 한다.

제시한 기법을 적용하게 되면 고효율의 소형송 전선을 구축할 수 있고, 같은 송전선 루트폭 내에 서 전력 수송력을 2 배 이상으로 증가시킬 수 있다.

\section{2. 본 론}

가공 송전용 철탑은 절연협조, 지지물 접지, 철 탑 기초, 전선 선정, 이도, 가공지선, 진동방지, 애 자장치 등의 복합적인 요소를 고려하여 설계 한다.

이중 철탑 설계의 핵심이 되는 절연협조 설계에 서는 상용주파 단시간 과전압에 의한 공기 절연거 리인 이상시 절연간격과 뇌전압에 대한 공기절연 간격인 표준절연간격 그리고 개폐과전압에 대한 공기절연거리인 최소절연간격이 필수적으로 고려 되어야 한다.

철탑은 도체를 지지하고 고전압이 걸린 도체의 공간적 절연 유지를 위하여 무거운 금속 암과 애 자련이 필요하고, 도체의 swing 공간을 고려하여 철탑 본체와 도체가 허용되는 거리를 유지하도록 철탑 암의 길이가 결정된다. 특히 철탑에서의 clearance(상-대지 절연)에 의해 철탑의 전선 배치 가 정해지며, 이러한 전선 배치는 철탑의 clearance diagram에 의한 수직·수평 선간거리와 바람의 움 직임의 정적 등가 환산에 의한 수직 · 수평 선간거 리로 크게 나누어 산출 되어 적용된다.

일반적으로 전선로의 설계상 표준으로 정하는 철탑의 중심 간의 거리인 경간에 의해 분류되어 정해진 표준 철탑을 기준으로 설계된다.

\section{1 송전설비 절연협조 설계검토}

2.1.1 절연설계 목표 과전압 배수

절연암을 이용한 송전설비의 절연협조의 목표가 되는 $345 \mathrm{kV}$ 송전선로의 목표 과전압 배수는 한전 설계 기준 -1032 을 기준으로 표 1 과 같다[4].

\subsection{2 절연설계 개폐과전압 배수}

직접접지방식 송변전설비의 개폐과전압 배수는 참고 문헌[5]에 명시된 값을 이용하여 구하였다. 최대과전압이 발생한 경우의 조건을 상정하여 상대지간 및 상간의 과전압배수를 전자계 과도현상 해석프로그램(EMTP:Electro-Magnetic Transient Program)을 이용하여 계산하고 재현확률을 고려하 여 과전압배수를 정하였다.
표 1. 절연설계 목표 과전압 배수.

Table 1. Over voltage for insulation design.

\begin{tabular}{|c|c|c|c|c|}
\hline 전압 & \multicolumn{2}{|c|}{ 구 분 } & $\begin{array}{l}\text { 과전압 } \\
\text { 배수 } \\
\text { [p.u.] }\end{array}$ & 1 p.u. 당 기준전압 \\
\hline \multirow{4}{*}{$345 \mathrm{kV}$} & \multirow{2}{*}{$\begin{array}{l}\text { 상용 주파 } \\
\text { 단시간 } \\
\text { 과전압 }\end{array}$} & $\begin{array}{c}\text { 상- } \\
\text { 대지간 }\end{array}$ & 1.35 & \multirow{2}{*}{$1 \mathrm{p} \cdot \mathrm{u}=\frac{362}{\sqrt{3}}[\mathrm{kV}]$} \\
\hline & & $\begin{array}{l}\text { 중성점- } \\
\text { 대지간 }\end{array}$ & 0.68 & \\
\hline & 개폐 & $\begin{array}{c}\text { 상- } \\
\text { 대지간 }\end{array}$ & 2.5 & 1 p.u $=\frac{\sqrt{2} \times 362}{\sqrt{3}}[\mathrm{kV}]$ \\
\hline & & 상 간 & 4.0 & \\
\hline
\end{tabular}

표 2. 개폐과전압 배수.

Table 2. Switching overvoltage.

\begin{tabular}{|c|c|c|c|c|c|c|}
\hline 전압 & \multicolumn{3}{|c|}{ 구 분 } & $\begin{array}{c}\text { Mean }(\mathrm{M} \\
\text { [p.u.] }\end{array}$ & $\begin{array}{c}\text { Standard } \\
\text { Deviation }(\sigma)\end{array}$ & $\begin{array}{l}\mathrm{M}+2 \sigma \\
\text { [p.u.] }\end{array}$ \\
\hline \multirow{4}{*}{$345 \mathrm{kV}$} & $\begin{array}{l}\text { 상 } \\
\text { 대 }\end{array}$ & 구성 & $\begin{array}{l}\mathrm{OH}^{+} \\
\mathrm{CA}\end{array}$ & \multirow{2}{*}{1.9815} & \multirow{2}{*}{0.2220} & \multirow{2}{*}{2.4255} \\
\hline & $\begin{array}{l}\text { 지 } \\
\text { 간 }\end{array}$ & $\begin{array}{l}\text { 기준 } \\
\text { 구간 }\end{array}$ & CA & & & \\
\hline & \multirow{2}{*}{$\begin{array}{l}\text { 상 } \\
\text { 간 }\end{array}$} & 구성 & $\begin{array}{l}\mathrm{OH}^{+} \\
\mathrm{CA}^{-}\end{array}$ & \multirow{2}{*}{3.0433} & \multirow{2}{*}{0.4765} & \multirow{2}{*}{3.9963} \\
\hline & & $\begin{array}{l}\text { 기준 } \\
\text { 구간 }\end{array}$ & $\mathrm{CA}$ & & & \\
\hline
\end{tabular}

[주] 1. OH : 가공 송전선로, $\mathrm{CA}$ : 송전용 케이블

표 2의 개폐과전압의 경우에 차단기에는 $520 \Omega$ 의 투입저항을 사용하고, 송전선의 길이는 가공부 분이 $120 \mathrm{~km}$, 지중케이블이 $21 \mathrm{~km}$ 혼재하여 있는 경우를 상정하였으며, 피뢰기는 선로의 양단 및 케 이블과 가공송전선의 접속점에 설치되어 있는 경 우로 하였다. 이 때, 통계계산은 매 200회로 하여 정규분포확률을 이용하였다.

상-대지간 개폐과전압 배수는 신뢰구간 $97.5 \%$ 로 설계하는 경우 표 2에서 보는 바와 같이 2.4 p.u.를 약간 상회하는 것으로 나타났으며, 상간 개 폐과전압 배수는 약 4.0 p.u.를 나타내고 있다.

\subsection{3 공기절연 특성에 대한 검토}

직접접지방식의 송변전설비의 공기절연 특성은 상용주파단시간과전압, 개폐과전압의 상-대지간 및 상간 특성, 뇌과전압에 대한 특성이 필수적으로 고 려되어야 한다. 


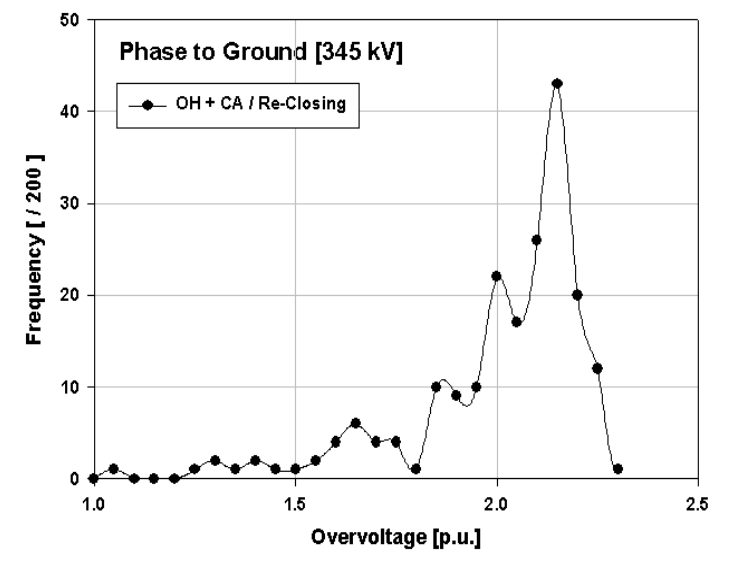

그림 1. $345 \mathrm{kV}$ 상-대지간 개폐과전압 발생빈도.

Fig. 1. Frequency of switching overvoltage for $345 \mathrm{kV}$ (phase-to-ground).

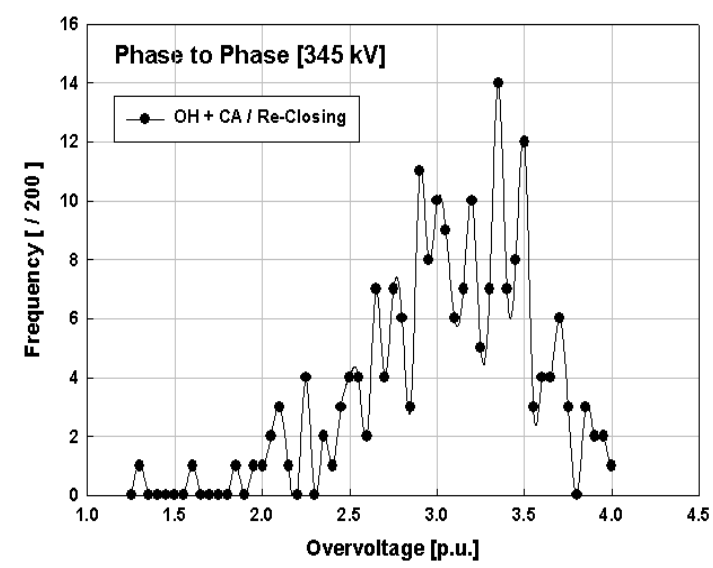

그림 2. $345 \mathrm{kV}$ 상간 개폐과전압 발생빈도.

Fig. 2. Frequency of switching overvoltage for $345 \mathrm{kV}$ (phase-to-phase).

국내의 연구 자료가 있는 개폐과전압의 상-대지간 특성에 대하여는 참고문헌[6]의 결과를 이용하고, 상용주파단시간과전압, 개폐과전압의 상간 특성 및 뇌과전압에 대한 특성은 일본 전력중앙 연구소의 실험식을 이용하였다[7].

○ 이상시 절연간격 $(\mathrm{D})$

상용주파 단시간과전압에 대한 $50 \%$ 섬락전압 계산은 식 (1)과 같이 계산된다[7,8].
표 3. 아킹혼 간격.

Table 3. Arcing horn gap.

\begin{tabular}{|c|c|c|}
\hline 전압별 & 구 분 & 아킹혼 간격 $[\mathrm{mm}]$ \\
\hline \hline \multirow{2}{*}{$345 \mathrm{kV}$} & 현수 & 2,340 \\
\cline { 2 - 3 } & 내장 & 2,340 \\
\hline
\end{tabular}

$$
\begin{aligned}
V_{50 \%}=\sqrt{\frac{2}{3}} \times V_{m} \times n \times k_{1} \times k_{2} . \\
\text { 단, } \quad V_{m}: \text { 계통최고전압의 실효치 }[\mathrm{kV}] \\
n: \text { 과전압 배수 } \\
k_{1}: \text { 기상보정계수 } \\
k_{2}: \text { 내압계수 }
\end{aligned}
$$

이 $50 \%$ 섬락전압에 대한 공기절연간격(d)은 식 (2)를 통해 계산 할 수 있다[8]. $345 \mathrm{kV}$ 의 경우 $\mathrm{V}_{\mathrm{m}}=362, \mathrm{n}=1.35, \mathrm{k}_{1}=1.165, \mathrm{k}_{2}=1.099$ 를 식 (1)에 대입하면 $\mathrm{V}_{50 \%}$ 는 $511 \mathrm{kV}$ 가 된다. 이때 식 (2)에 의 하여 $\mathrm{d}$ 는 $990 \mathrm{~mm}$ 가 되며, 상용주파 단시간 과전 압에 의한 공기 절연거리인 이상시 절연간격 설계 적용값은 $1,000 \mathrm{~mm}$ 로 하였다.

$$
V_{50 \%}=1.26 \cdot 1,080 \cdot \ln (0.46 \cdot d+1)
$$

\section{○ 표준절연간격 $(\mathrm{A})$}

표준절연간격은 뇌에 의한 섬락을 아킹혼 간으 로 유도하기 위하여 도체-하단암 간에 유지하는 간격으로 다음 식으로 산출한다.

$$
\begin{aligned}
& \text { 표준절연간격 }=1.115 Z+0.021[\mathrm{~m}] \\
& \text { 단, } Z: \text { 아킹혼 간격 }[\mathrm{m}]
\end{aligned}
$$

여기서 아킹혼 간격 $Z$ 는 표 3 과 같이 한전 설 계기준-1032 값을 적용한다. 식 (3)에 아킹혼 간격 $\mathrm{Z}=2,340 \mathrm{~mm}$ 를 대입하면 $\mathrm{A}=2,609 \mathrm{~mm} \fallingdotseq 2,700 \mathrm{~mm}$ 가 된다.

○ 최소절연간격 (b)

최소 절연간격은 개폐과전압에 의한 섬락을 아 킹혼 간으로 유도하기 위하여, 도체-하단암, 도체탑체, 도체-상단암간에 유지하는 간격으로, 도체와 상하단암 및 탑체간의 개폐내전압 특성으로부터 산출한다[6].

(1) 상-대지간 공기절연거리

$$
V_{50 \%}=k \cdot 950 \cdot \ln (0.57 \cdot d+1)[\mathrm{kV}]
$$


표 4. 현수형 애자련의 개폐과전압에 대한 공 기절연거리.

Table 4. Clearance distance according to switching overvoltage for suspension string.

\begin{tabular}{|c|c|c|c|c|c|}
\hline 전압 & \multicolumn{3}{|c|}{ 구분 } & 계산 & 적용값 \\
\hline \hline \multirow{3}{*}{345} & 도체- & 3각암 & $\mathrm{k}=1.48$ & $1,670 \mathrm{~mm}$ & $1,700 \mathrm{~mm}$ \\
\cline { 2 - 6 } $\mathrm{kV}$ & 하단암 & 4각암 & $\mathrm{k}=1.37$ & $1,859 \mathrm{~mm}$ & $1,900 \mathrm{~mm}$ \\
\cline { 2 - 6 } & \multicolumn{2}{|c}{ 도체-탑체 } & $\mathrm{k}=1.24$ & $2,143 \mathrm{~mm}$ & $2,200 \mathrm{~mm}$ \\
\cline { 2 - 6 } & \multicolumn{2}{|c|}{ 상간 절연간격 } & & $3,183 \mathrm{~mm}$ & $3,200 \mathrm{~mm}$ \\
\hline
\end{tabular}

표 5. 내장형 애자련의 개폐과전압에 대한 공 기절연거리.

Table 5. Clearance distance according to switching overvoltage for tension string.

\begin{tabular}{|c|c|c|c|c|c|}
\hline \multirow{2}{*}{ 전압 } & \multicolumn{3}{|c|}{ 구분 } & 계산 & 적용 \\
\hline \hline \multirow{3}{*}{345} & 도체- & 3각암 & $\mathrm{k}=1.32$ & $1,959 \mathrm{~mm}$ & $2,000 \mathrm{~mm}$ \\
\cline { 2 - 6 } $\mathrm{kV}$ & 하단암 & 4각암 & $\mathrm{k}=1.25$ & $2,118 \mathrm{~mm}$ & $2,200 \mathrm{~mm}$ \\
\cline { 2 - 6 } & \multicolumn{2}{|c}{ 도체-탑체 } & $\mathrm{k}=1.24$ & $2,143 \mathrm{~mm}$ & $2,200 \mathrm{~mm}$ \\
\cline { 2 - 6 } & 상간 절연간격 & & $3,183 \mathrm{~mm}$ & $3,200 \mathrm{~mm}$ \\
\hline
\end{tabular}

$50 \%$ 섬락전압의 계산식 (1)에 $V_{m}=362, n=2.5$, $k 1=1.082, k 2=1.176$ 를 각각 대입하면 $\mathrm{V}_{50 \%}$ 는 940 $\mathrm{kV}$ 가 된다. 이 결과를 개폐과전압에 대한 공기절 연거리 계산 실험식 식 (4)에 대입하여 공기절연거 리의 계산 가능하다.

(2) 상간 공기절연거리

$$
V_{50 \%}=2,570 \cdot \ln (0.25 \cdot d+1)[\mathrm{kV}]
$$

$50 \%$ 섬락전압의 계산식 (1)에 $V_{m}=362, n=4.0$, $k 1=1.082, k 2=1.176$ 를 각각 대입하면 임계섬락전 압을 구하고, 이 결과를 계폐과전압에 대한 상간의 공기절연거리 계산 식 (5)에 대입하여 공기절연거 리의 계산 가능하다.

현수형과 내장형 애자련을 고려해서 개폐과전압 에 대한 공기절연거리(최소절연간격) 계산 결과 및 설계 적용값을 정리하면 표 4 및 표 5 와 같다.

2.1.4 폴리머 절연암의 연면 누설거리

적용되는 폴리머 절연암의 외형은 그림 3 과 같

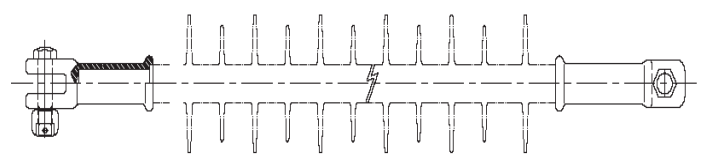

그림 3. 폴리머 절연암 외형도.

Fig. 3. Appearance of polymer insulation arm.

표 6. 염해 오손등급별(ESDD) 연면누설거리.

Table 6. Creeping distance according to classification of esdd level.

\begin{tabular}{|c|c|c|c|c|c|}
\hline 오손등급 & 청정 & $\mathrm{A}$ & $\mathrm{B}$ & $\mathrm{C}$ & $\mathrm{D}$ \\
\hline $\mathrm{ESDD}\left[\mathrm{mg} / \mathrm{cm}^{2}\right]$ & 0.03 이하 & 0.063 & 0.125 & 0.25 & 0.5 \\
\hline 누설거리[mm] & - & 6445 & 7820 & 8290 & 9670 \\
\hline
\end{tabular}

으며, 철탑과 가공선로 연결을 위한 금구가 양쪽 끝단에 위치해 있으며, 내부 절연 및 기계적 강도 를 담당하는 심재(Core)로 FRP(Fiber Reinforced Plastics)가 사용되며, 심재를 보호하면서 외부환경 에 의한 오손 특성 확보를 위해 실리콘 혹은 $\mathrm{EPDM}$ 등의 절연재료를 사용해 심재 감싸는 외피 인 하우징과 갓(Shed)으로 이루어져 있다[9].

아킹혼의 연면 누설거리는 계통의 최고 운전전 압을 적용하는 것이 타당하므로 현재의 $345 \mathrm{kV}$ 계 통 최고운전전압인 $362 \mathrm{kV}$ 를 적용하는 것을 기본 으로 한다. $345 \mathrm{kV}$ 4도체 송전선로에서 $210 \mathrm{kN}$ 보통애자를 사용하는 청정 및 오손구분 $\mathrm{A}$ 지역의 예를 들면, 소요 연면누설거리는 $17.8 \mathrm{~mm} / \mathrm{kV} \times$ $362 \mathrm{kV}=6,444 \mathrm{~mm}$ 가 되고, 각각의 오손 지역별 소요 연면누설거리는 표 6과 같다. 폴리머 절연암 의 연면 누설거리는 절연암 갓의 수 및 형상에 의 해 결정되므로 오손 지역과 관계없이 동일한 절연 암을 사용하기 위해서는 연면 누설거리를 9,670 $\mathrm{mm}$ 이상으로 제조하여 적용한다.

\subsection{5 절연설계에 따른 철탑 형상}

기설 $154 \mathrm{kV}$ 송전선로의 $345 \mathrm{kV}$ 전압 격상을 위해 기존 철재암을 철거하고 절연암을 적용하였 을 경우, 필요한 절연거리에 대한 검토를 하였다. 그 결과 현재 운전 중인 $154 \mathrm{kV}$ 철탑보다 작은 크 기의 철탑으로 $345 \mathrm{kV}$ 로 승압하는 것이 가능함을 알 수 있다. 대표적인 현수형 및 내장형의 철탑형 상은 그림 4 및 5 와 같다. 

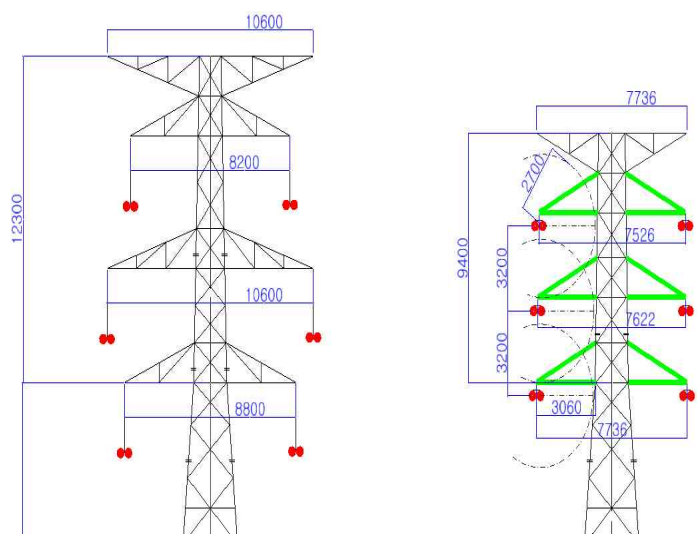

그림 4. 절연설계에 따른 철탑 형상 - 현수형.

Fig. 4. Configuration of tower according to insulation design for suspension string.
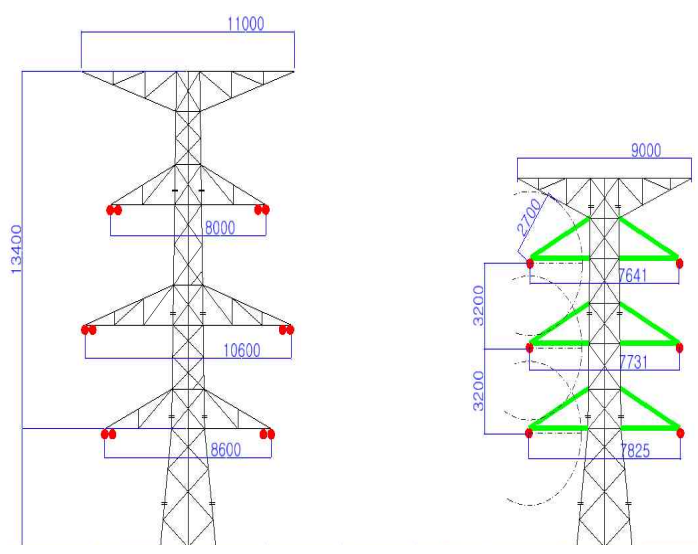

그림 5. 절연설계에 따른 철탑 형상 - 내장형.

Fig. 5. Configuration of tower according to insulation design for tension string.

\subsection{6 뇌 사고율 계산}

뇌사고율의 계산프로그램은 EPRI의 FLASH를 이용하는 것을 기본으로 하고 EMTP(Electro-Mag netic Transient Program)를 이용한 역섬락전류 계 산과 자체 개발한 뇌사고율 프로그램을 이용하여 계산하였다[8]. 뇌 사고율 계산을 위해 사용된 기 본 입력데이터 및 도체 좌표 데이터는 그림 6 및 표 7과 같다.

대지경사각에 따른 뇌 사고율 계산 결과는 표 8 과 같다. 계산 결과에서 알 수 있듯이 대지경사각 이 20 도인 경우까지 뇌 사고율은 설계 목표치인 1 [건/100 km - 년]이하로 만족함을 알 수 있다.

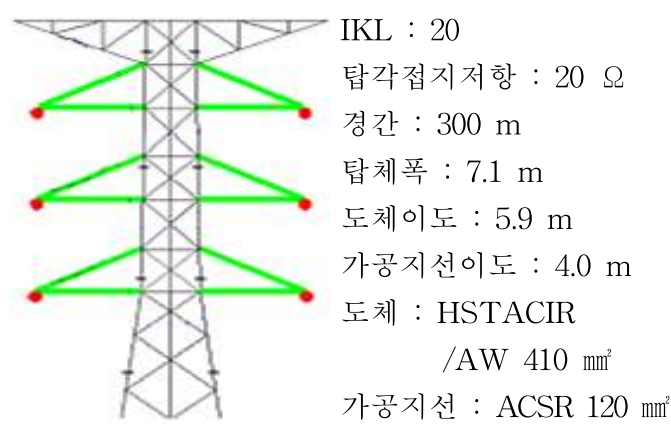

그림 6. 뇌 사고율 계산 기본 입력 데이터.

Fig. 6. Data for lightning flashover rate.

표 7. 도체 좌표 데이터.

Table 7. Conductor position.

\begin{tabular}{|c|c|c|c|c|c|c|c|c|}
\hline \multirow[b]{2}{*}{ No } & \multirow[b]{2}{*}{ 기능 } & \multicolumn{2}{|c|}{ 도체 위치 } & \multirow[b]{2}{*}{$\begin{array}{l}\text { 도체 } \\
\text { 직 경 } \\
{[\mathrm{cm}]}\end{array}$} & \multirow[b]{2}{*}{$\begin{array}{l}\text { 번 } \\
\text { 들 } \\
\text { 수 }\end{array}$} & \multirow{2}{*}{\begin{tabular}{|c|} 
번 \\
들 \\
간 \\
격 \\
{$[\mathrm{cm}]$}
\end{tabular}} & \multirow[b]{2}{*}{$\begin{array}{l}\text { 운전 } \\
\text { 전압 } \\
{[\mathrm{kV}]}\end{array}$} & \multirow[b]{2}{*}{$\begin{array}{c}\text { 위상 } \\
\text { 각 } \\
\text { [도] }\end{array}$} \\
\hline & & $\begin{array}{c}\mathrm{X} \\
{[\mathrm{m}]}\end{array}$ & $\begin{array}{c}\mathrm{Y} \\
{[\mathrm{m}]}\end{array}$ & & & & & \\
\hline 1 & 차폐 & -4.7 & 42.34 & 1.75 & & & & \\
\hline 2 & 차폐 & 4.7 & 42.34 & 1.75 & & & & \\
\hline 3 & A & -4.7 & 38.84 & 2.85 & 2 & 40 & 345 & 0 \\
\hline 4 & B & -4.7 & 35.34 & 2.85 & 2 & 40 & 345 & -120 \\
\hline 5 & $\mathrm{C}$ & -4.7 & 31.84 & 2.85 & 2 & 40 & 345 & 120 \\
\hline 6 & $\mathrm{C}^{\prime}$ & 4.7 & 38.84 & 2.85 & 2 & 40 & 345 & 120 \\
\hline 7 & $\mathrm{~B}^{\prime}$ & 4.7 & 35.34 & 2.85 & 2 & 40 & 345 & -120 \\
\hline 8 & $\mathrm{~A}^{\prime}$ & 4.7 & 31.84 & 2.85 & 2 & 40 & 345 & 0 \\
\hline
\end{tabular}

표 8. 뇌 사고율 평가 결과.

Table 8. Evaluation of lightning flashover rate.

[건 $/ 100 \mathrm{~km} \cdot$ 년]

\begin{tabular}{|c|c|c|c|}
\hline $\begin{array}{c}\text { 대지 } \\
\text { 경사각(도) }\end{array}$ & $\begin{array}{c}\text { 차폐실패 } \\
\text { 사고율 }\end{array}$ & $\begin{array}{c}\text { 역섬락 } \\
\text { 사고율 }\end{array}$ & $\begin{array}{c}\text { 총 } \\
\text { 뇌사고율 }\end{array}$ \\
\hline \hline 0 & 0 & 0.746 & 0.746 \\
\hline 5 & 0.012 & 0.746 & 0.758 \\
\hline 10 & 0.035 & 0.746 & 0.781 \\
\hline 15 & 0.088 & 0.745 & 0.833 \\
\hline 20 & 0.198 & 0.744 & 0.941 \\
\hline
\end{tabular}




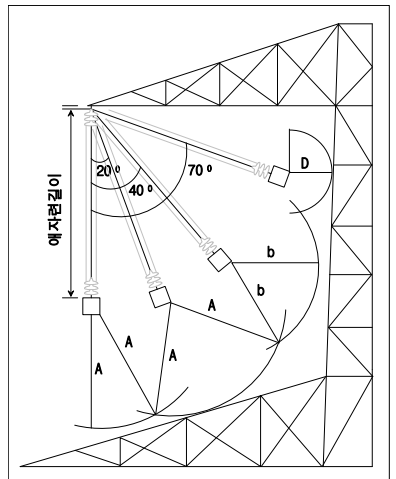

[단위 : $\mathrm{mm}$ ]

\begin{tabular}{|c|c|}
\hline 기호 & 거리 \\
\hline \hline $\mathrm{A}$ & 2,700 \\
\hline $\mathrm{b}$ & 2,200 \\
\hline $\mathrm{D}$ & 1,000 \\
\hline$\ominus 1$ & $20^{\circ}$ \\
\hline$\ominus 2$ & $40^{\circ}$ \\
\hline$\ominus 3$ & $70^{\circ}$ \\
\hline
\end{tabular}

(a) 4도체 현수형

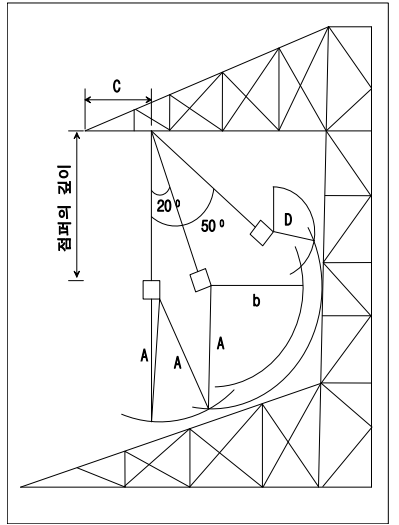

[단위 : $\mathrm{mm}$ ]

(b) 4도체 내장형

그림 7. $345 \mathrm{kV}$ 철탑 clearance diagram.

Fig. 7. Clearance diagram of $345 \mathrm{kV}$ transmission tower.

\section{2 철탑구조설계}

절연설계로 결정된 $345 \mathrm{kV}$ 절연암 철탑형상에 대하여 도체와 탑체간 수평거리, 수직상간거리등에 대하여 검토하고 최종적인 철탑형상을 결정하였다.

절연암 하중은 현수형, 내장형 철탑에 대하여 검토 한 후 최대 하중을 상정하여 결정하였다.

\subsection{1 수평선간거리}

○ 표준철탑의 수평선간거리

수평선간거리는 도체와 철탑 탑체간의 Clearance Diagram에 의하여 결정되며 이에 따라 철탑암 길 이가 결정된다. 표준철탑의 Clearance Diagram은 그림 7과 같다. 여기서 기호 $\mathrm{A}(\theta 1)$ 는 표준절연간 격, $\mathrm{b}(\theta 2)$ 는 최소절연간격, $\mathrm{D}(\theta 3)$ 는 이상시 절 연간격을 나타낸다.

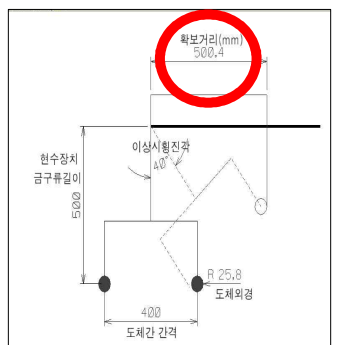

(a) 현수형

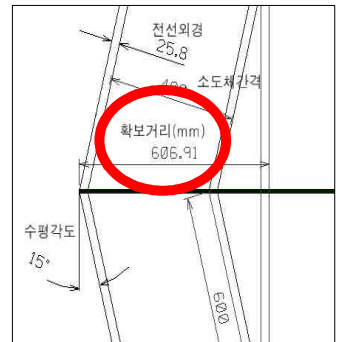

(b) 내장형
그림 8. 절연암 적용시 고려되는 길이.

Fig. 8. Distance considering polymer insulation arm.

\subsection{2 절연암 적용시 수평선간거리}

절연암을 적용할 경우 현수철탑에서는 애자련을 사용하지 않고 내장철탑에서도 점퍼의 길이와 폭 이 대폭 축소됨으로써 점퍼의 횡진 또한 고려하지 않는다. 따라서 절연암 적용시 수평선간거리는 절 연설계에 따른 거리와 현수장치 횡진길이, 내장철 탑 Jumper선의 이동길이를 고려하여 결정한다.

\section{○현수형 철탑}

그림 8(a)처럼 현수장치 횡진시 확보되는 거리 500.4 $\mathrm{mm}$ 를 고려하여 정리하면, $345 \mathrm{kV}$ 현수형 절연암 길이는 $3,200 \mathrm{~mm}(2,700 \mathrm{~mm}+500 \mathrm{~mm})$ 로 선정

- $345 \mathrm{kV}$ 표준절연거리 : $2,700 \mathrm{~mm}$

- 금구류(현수장치) 횡진시 탑체로 근접하는 길이 : $500 \mathrm{~mm}$

○ 내장형 철탑

그림 8(b)처럼 Jumper선이 탑체로 근접하는 거 리를 고려하여 정리하면, $345 \mathrm{kV}$ 내장형 절연암길 이는 $3,300 \mathrm{~mm}(2,700 \mathrm{~mm}+600 \mathrm{~mm})$ 로 선정

- $345 \mathrm{kV}$ 표준절연거리 : $2,700 \mathrm{~mm}$

- 내장철탑(삼각암, $30^{\circ}$ ) Jumper선이 탑체로 근접하는 거리 : $600 \mathrm{~mm}$

○ 절연암 길이 결정 : 현수철탑과 내장철탑 검 토결과 내장철탑의 절연암 길이 $3,300 \mathrm{~mm}$ 를 선정 하여 공통으로 적용

하단암에서 철탑주주재와 이격거리 검토 철탑주주재 기울기를 고려하여 하단암에서 철탑 주주재까지 절연거리 $2,700 \mathrm{~mm}$ 를 확보하는지 검 토한 결과 그림 9 에서 알 수 있듯이 현수철탑은 $3,034 \mathrm{~mm}$, 내장철탑은 $2,811 \mathrm{~mm}$ 로 절연거리 확보 가 가능하다. 


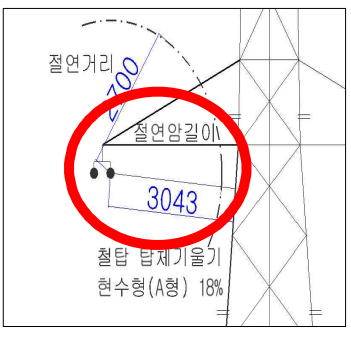

(a) 현수형

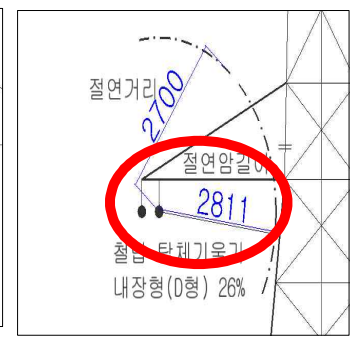

(b) 내장형

그림 9. 절연암 적용시 하단암에서 철탑주주재와 이격거리.

Fig. 9. Clearance distance considering polymer insulation arm.

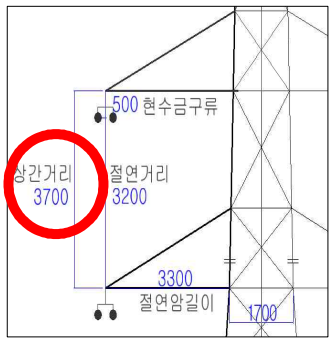

(a) 현수형

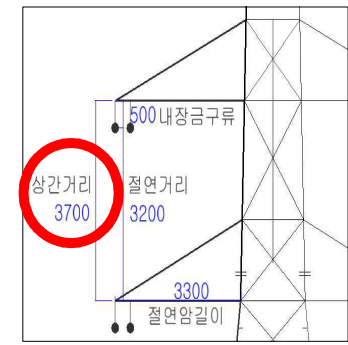

(b) 내장형

그림 10. 절연암 적용시 고려되는 길이.

Fig. 10. Distance considering polymer insulation arm.

\subsection{3 절연암 적용시 수직선간거리}

절연암을 적용할 경우 수평선간거리 설계에서와 같이 현수철탑에서는 애자련이 없고 내장철탑에서 는 점퍼선이 최소화되므로 절연암 적용시 수직선 간거리는 절연설계에 따른 거리와 금구류의 길이 를 고려하여 결정한다.

\section{현수철탑}

그림 10(a)처럼 현수장치의 금구류 거리와 상간 절연거리를 고려하여 정리하면, 상간거리는 3,700 $\mathrm{mm}(3,200 \mathrm{~mm}+500 \mathrm{~mm})$ 로 선정

- $345 \mathrm{kV}$ 상간절연거리 : $3,200 \mathrm{~mm}$

- 현수장치 금구류 길이 : $500 \mathrm{~mm}$

\section{○ 내장철탑}

그림 10(b)처럼 내장장치 Jumper선 폭과 상간절 연거리를 고려하여 정리하면, 상간절연거리는 3,700 $\mathrm{mm}(3,200 \mathrm{~mm}+500 \mathrm{~mm})$ 로 선정

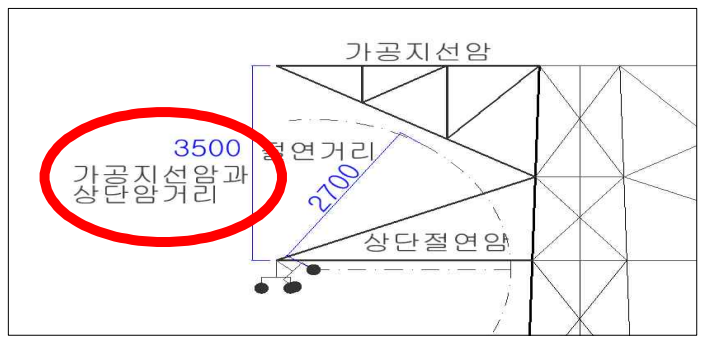

그림 11. 가공지선암 $(\mathrm{OPGW})$ 과 상단암 거리.

Fig. 11. Distance between OPGW arm and upper arm.

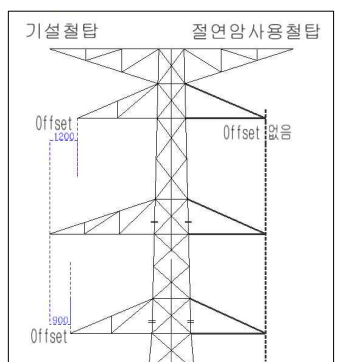

(a) 수직 Offset

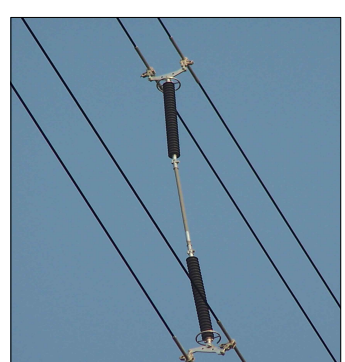

(b) 상간 스페이서
그림 12. 철탑의 수직 Offset.

Fig. 12. Tower vertical offset.

- $345 \mathrm{kV}$ 상간절연거리 : $3,200 \mathrm{~mm}$

- 내장장치 Jumper선 폭 : $500 \mathrm{~mm}$

○ 수직선간거리 : 현수철탑과 내장철탑 공통으 로 $3,700 \mathrm{~mm}$ 를 적용하도록 한다.

○ 가공지선암과 상단암과의 수직선간 거리

가공지선 암은 전압이 인가되어 있지 않으므로 그림 11에서처럼 상단암과의 간격은 $345 \mathrm{kV}$ 표준 절연간격에 철탑 높이를 고려 $3,500 \mathrm{~mm}$ 로 선정한다.

\subsubsection{Offset}

2회선 수직배열 표준철탑의 경우 Sleet Jump, Galloping 등으로 인한 단락고장을 방지하기 위하여 Offset을 적용하고 있으나 절연암을 적용한 철탑에 서는 절연암의 규격을 통일하기 위하여 그림 $12(\mathrm{a})$ 처럼 Offset을 고려하지 않고 Sleet Jumper나 Galloping이 발생하는 개소는 그림 $12(\mathrm{~b})$ 와 같은 $345 \mathrm{kV}$ 상간스페이서를 설치하여 단락고장을 예방 하도록 한다. 


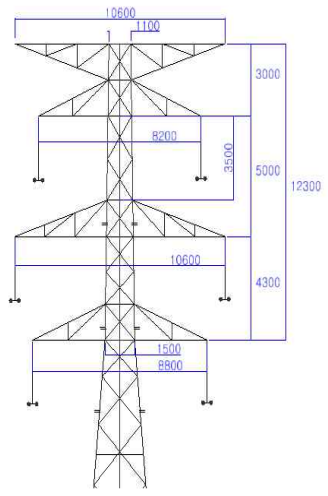

(a) $154 \mathrm{kV}$ 표준철탑

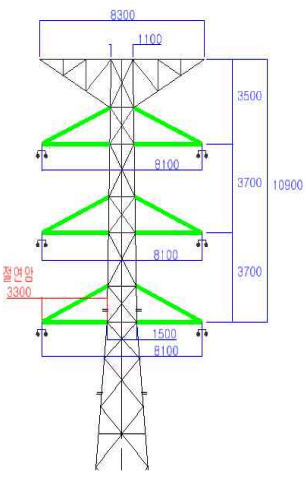

(b) 절연암 $345 \mathrm{kV}$ 철탑

그림 13. 최종 현수형 철탑.

Fig. 13. Configuration of transmission tower for suspension string.

\section{3. 결과 및 고찰}

\section{1 최종 철탑형상}

최종 형상은 표준철탑을 대상으로 탑체폭에 따 라 현수형 $(1,500 \mathrm{~mm})$ 과 내장형 $(1,700 \mathrm{~mm})$ 으로 나 누었으며 상-중-하단의 절연암은 동일규격으로 개발하고 상부 탑체폭 Slope에 따른 암길이 조정 은 별도의 금구류를 사용하여 수평선간거리를 동 일하게 한다.

\subsection{1 현수형}

$154 \mathrm{kV}$ 표준철탑은 그림 13(a)와 같은 $\mathrm{A}$ 형이며 현수형 철탑중 $\mathrm{A}, \mathrm{F}$ 형은 탑체폭이 $1,500 \mathrm{~mm}$ 로 동 일하기 때문에 그림 13(b)와 같은 절연암 적용 345 $\mathrm{kV}$ 현수형 철탑을 사용한다. $154 \mathrm{kV}$ 표준철탑 $\mathrm{SF}$ 형은 탑체폭이 $1,700 \mathrm{~mm}$ 로 내장형과 동일하기 때 문에 절연암 적용 $345 \mathrm{kV}$ 내장형 철탑을 사용한다.

\subsection{2 내장형}

$154 \mathrm{kV}$ 표준철탑은 그림 $14(\mathrm{a})$ 와 같은 $\mathrm{D}$ 형이며 내장형 $(\mathrm{B}, \mathrm{C}, \mathrm{E}, \mathrm{D})$ 철탑은 모두 그림 $14(\mathrm{~b})$ 와 같은 절 연암 적용 $345 \mathrm{kV}$ 내장형 철탑으로 형상이 결정된다.

\subsection{3 절연암 적용 철탑 세부형상}

절연암을 적용한 철탑의 세부형상은 그림 15 와 같이 정리 할수 있으며 그럼에서 알 수 있듯이 현 수형과 내장형의 큰차이는 없으며 탑체폭의 길이에 따라 절연암 주주재 및 절연암 보조재의 길이가 변동됨을 알 수 있다.

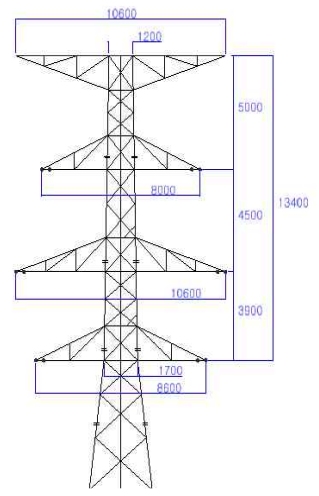

(a) $154 \mathrm{kV}$ 표준철탑

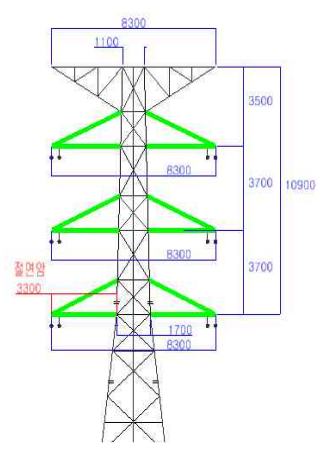

(b) 절연암 $345 \mathrm{kV}$ 철탑
그림 14. 최종 내장형 철탑.

Fig. 14. Configuration of transmission tower for tension string.

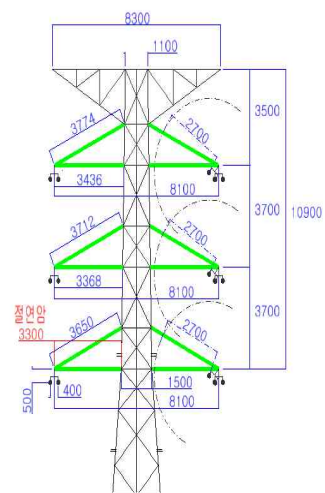

(a) 현수 철탑

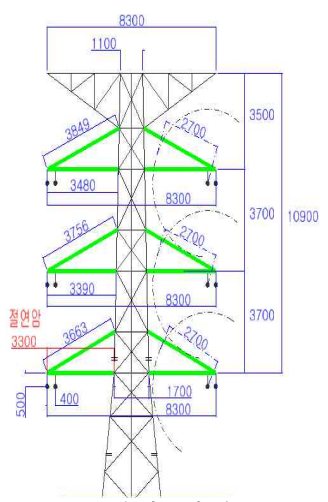

(b) 내장 철탑
그림 15 . 절연암 적용 철탑.

Fig. 15. Transmission tower using polymer insulation arm.

표 ․ㅓㄹ탑 크기 증감내역.

Table 9. Tower size reduction.

\begin{tabular}{|c|c|c|c|c|}
\hline \multirow{2}{*}{ 철탑형 } & 구 분 & $154 \mathrm{kV}$ & $\begin{array}{c}\text { 절연암 } \\
\text { 적용 }\end{array}$ & 증 감 \\
\hline \hline \multirow{2}{*}{$\mathrm{A}$} & 철탑 상부높이 & $12,300 \mathrm{~mm}$ & $10,900 \mathrm{~mm}$ & $\triangle 1,400 \mathrm{~mm}$ \\
\cline { 2 - 5 } & 최대 철탑폭 & $10,600 \mathrm{~mm}$ & $8,300 \mathrm{~mm}$ & $\triangle 2,300 \mathrm{~mm}$ \\
\hline \multirow{2}{*}{$\mathrm{D}$} & 철탑 상부높이 & $13,400 \mathrm{~mm}$ & $10,900 \mathrm{~mm}$ & $\triangle 2,500 \mathrm{~mm}$ \\
\cline { 2 - 5 } & 최대 철탑폭 & $10,600 \mathrm{~mm}$ & $8,300 \mathrm{~mm}$ & $\triangle 2,300 \mathrm{~mm}$ \\
\hline
\end{tabular}

절연암을 채용함에 따라 철탑별 상부높이 및 철 탑폭 증감내역을 정리하면 표 9와 같다. 


\section{4. 결 론}

본 논문에서 제안된 절연암을 사용한 철탑 설계 적용 시 경과지 확보가 어려운 도심의 주변지역의 전력수송력 증강 대책의 일환으로 기존 $154 \mathrm{kV}$ 송 전선로 경과지에 $345 \mathrm{kV}$ 송전이 가능하여, 같은 송전선 루트폭 내에서 전력 수송력을 2 배 이상으 로 증가시킬 수 있다. 또한 기존 철탑과 비교하여 절연암을 사용함으로서 철탑 구축이 상대적으로 용이하다. 절연암은 비도전체이기 때문에 같은 용 량과 크기의 철탑에서의 철탑암에 해당하는 부재 를 줄일 수 있어 시공무게로 저감이 역시 가능하다. 탑체 크기의 감소로 인해 법적 용지매입이 감소 하고 환경친화형 탑체가 가능할 뿐만 아니라 철 탑의 형상설계를 달리하여 절연 특성을 만족하면 서 고효율의 소형송전선을 구축할 수 있는 기술개 념을 확립하였다.

\section{참고 문헌}

[1] D. Dumora, D. Feldman, and M. Gaudry, "Mechanical behavior of flexurally stressed composite insulators", IEEE Transactions on Power Delivery, Vol. 5, No. 2, p. 1066, 1990.
[2] M. Otsubo, Y. Shimono, T. Hikami, C. Honda, and $\mathrm{K}$. Ito, "Influence of the humidity on leakage current under accelerated aging of polymer insulating materials", Conference Record of the 1996 IEEE International Symposium on Electrical Insulation, Vol. 1, p. 267, 1996.

[3] K. lzumi, T. Takahashi, T. Taniguchi, H. Homma, and T. Kuroyagi, "Performance of line post type polymer insulation arm for 154 $\mathrm{kV}^{\prime \prime}$, 10th International Symposium on High Voltage Engineering, p. 25, 1997.

[4] 한국전력공사 송전분야 설계기준-1031 “직접접 지방식 송변전설비 절연협조 기준”, 2003.

[5] 전력연구원, “345 kV 및 $154 \mathrm{kV}$ Gapless형 피 뢰기 정격 규격 및 기준정립 연구”, 2000.

[6] 전력연구원 "765 kV송전선로 공기절연거리 실 증연구”, 최종보고서, p. 152, 1996.

[7] Electrical Design Handbook for AC Overhead Transmission Lines from $187 \mathrm{kV}$ to 1,100 $\mathrm{kV}, 1986$.

[8] 전력연구원, “765 kV 계통 절연협조 연구”, 최 종보고서, 1995 .

[9] 이병성, 김찬영, 한재홍, "배전용 폴리머애자의 현장열화 특성평가", 전기전자재료학회논문지 13권, 10호, p. 847, 2000. 